\title{
Using life cycle costing (LCC) to select circular measures: A discussion and practical approach
}

Marianna Lena Kambanou and Tomohiko Sakao

The self-archived postprint version of this journal article is available at Linköping University Institutional Repository (DiVA):

http://urn.kb.se/resolve?urn=urn:nbn:se:liu:diva-163544

N.B.: When citing this work, cite the original publication.

Kambanou, M. L., Sakao, T., (2020), Using life cycle costing (LCC) to select circular measures: A discussion and practical approach, Resources, Conservation and Recycling, 155, .

https://doi.org/10.1016/j.resconrec.2019.104650

Original publication available at:

https://doi.org/10.1016/j.resconrec.2019.104650

Copyright: Elsevier

http://www.elsevier.com/

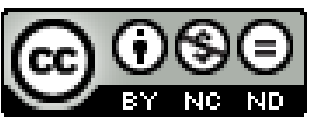




\title{
Using Lifecycle Costing to select circular measures: a discussion and practical approach
}

\author{
Marianna Lena Kambanou ${ }^{a}$ (corresponding author, email: marianna.kambanou@liu.se) \\ Tomohiko Sakao (email: tomohiko.sakao@liu.se) \\ a Division of Environmental Technology and Management, Department of Management and Engineering, \\ Linköping University, SE-581 83, Linköping, Sweden
}

\section{Abstract}

The implementation of circular measures in businesses constitutes a solution to future resource scarcity, which has yet to gain momentum. To select and implement such measures, companies, with limited resources need practical and easy-to-use guides that help them understand the financial outcomes while leading them towards more circular solutions. To this end, a guideline based on Lifecycle Costing (LCC), which fulfils the aforementioned criteria, has been created. The guideline directs the companies towards measures at the top of the CE hierarchy and LCC is used to assess profitability and provide information on material circularity. Its development follows the Design Research Methodology (DRM) and is based on using LCC at three case companies when selecting circular measures and on literature. Insights on the companies' process and decision criteria as well as the LCC results are presented. One identified critical criterion is the profitability of a circular measure, but comparing the LCC of alternatives is only an adequate measure of profitability, if the alternatives are functionally equivalent and of equal value for the customer, otherwise revenue and customer costs need to be compared as well. In addition, because labour is included in LCC, by categorizing the costs companies can be guided towards exchanging material costs with labour costs. Concerning circularity, in this comparative context, the difference in material cost between the alternatives can be used to measure circularity performance without additional effort. Finally, customization of products was also identified in the company research as a barrier to the implementation of various circular measures.

\section{Keywords}

Circular economy, circularity strategy, case study, resource efficiency, prescriptive research, product-service systems 


\section{INTRODUCTION}

There is large uncertainty whether demand for material resources which is expected to more than double from 2015 to 2050, can be met within the current linear take - make - use - dispose model (International Resource Panel, 2017). By using products and materials longer and/or more intensively, by minimizing waste and pollution and by assisting the natural regeneration, a circular economy (CE) aims at better utilization of material resources, mitigation of environmental impacts and ensuring economic prosperity (Ellen MacArthur Foundation, 2017). Moving towards a CE requires the involvement of a variety of actors e.g. government, industry and business, and is driven both top-down and bottom-up (Ghisellini, Cialani, \& Ulgiati, 2016; Lieder \& Rashid, 2016). The bottom-up drive is still limited and the widespread adoption of promising circular strategies by companies has not yet taken off, not because of technological limitations but often due to business and market challenges (Babbitt, Gaustad, Fisher, Chen, \& Liu, 2018; Kirchherr et al., 2018; Ranta, Aarikka-Stenroos, Ritala, \& Mäkinen, 2018). A main challenge for established companies is a lack of understanding of available circular measures and their ensuing effects on the business e.g. financial and environmental outcome (ibid.). Another challenge is that most companies and especially SMEs are hesitant as well as lack the resources needed to implement large change (Kirchherr et al., 2018; Rizos et al., 2016). Therefore, to stimulate the bottom-up driven adoption of circular measures established companies need easy-to-use support in (i) selecting and defining circular measures that are appropriate for their existing offerings or products and (ii) linking these measures to financial outcomes and contributions to resource efficiency (Allwood, Ashby, Gutowski, \& Worrell, 2011; Saidani, Yannou, Leroy, \& Cluzel, 2017).

To meet these requirements, a guideline is developed based on Lifecycle Costing (LCC), a quasi-dynamic method for calculating costs of an offering over the lifecycle (Hunkeler, Lichtenvort, \& Rebitzer, 2008). LCC is selected because it is a widely used method (ibid.) and meets a number of requirements mentioned above. Firstly, LCC's unit of analysis is an offering or its functionality. Secondly, LCC has a lifecycle perspective, which is crucial to $\mathrm{CE}$ but also provides key financial information to companies on costs covered by other stakeholders, which they might take over or influence when applying circular measures (Ghisellini et al., 2016; Lindahl, Sundin, \& Sakao, 2014; Tukker, 2015). Thirdly, LCC is relatively simple for practitioners to use due to the familiarity of the monetary metric and the availability of data (Gluch \& Baumann, 2004). Moreover, LCC is flexible and calculations can be further simplified by excluding costs that are identical when the purpose is to compare alternatives (IEC, 2017). This relative simplicity can be an advantage because, as mentioned, companies have limited resources e.g. time and knowledge to invest in applying circular measures, and more generally, tools with a high complexity are known to result in low implementation (Tomiyama et al., 2009). Finally, if a company wants to measure environmental impacts, then LCC can be complemented by its environmental counterpart, Lifecycle Assessment (LCA), which is the most comprehensive method for assessing the environmental impacts of an offering across the lifecycle

(Baumann \& Tillman, 2004; Finnveden \& Moberg, 2005). LCA is however not included in this guideline due to the large inputs required for joint implementation of LCA and LCC (D'Incognito, Costantino, \& Migliaccio, 2015). After the identification of LCC as a potentially useful method to be used when selecting circular measures, there is a need to explore in more detail the role it can play. Therefore, the first research question is formulated as:

RQ1. What are the strengths and limitations of companies using LCC to select circular measures for their offerings?

Because of a lack of published research on how circular strategies are selected generally and of the role LCC can play in this process specifically, case study research was used. More specifically LCC was introduced in the process of choosing circular measures at three real companies for five offerings. The findings from these cases, complimented by literature on LCC were used to answer RQ1.

Once the role LCC could play was identified, it needed to be integrated into a decision-making processes for selecting circular measures. Therefore, the second research question is:

RQ2. How can a guideline to choose circular measures using LCC be formulated? 
The findings from RQ1, the insights from observing the companies' process of selecting circular measures as well as published literature on circular measures and their appropriateness for certain products groups was used to design the guideline.

Key definitions are given in Section 2 and the research process is described in Section 3. The case studies, insights and LCC results are detailed in Section 4. RQ1 and RQ2 are answered in Sections 5 and 6 respectively and followed by discussions and conclusions in Section 7.

\section{KEY DEFINITIONS}

The key terms: offering, LCC and circular measures are presented here.

Offering: The term offering is used in this article to indicate products and/or services. The expressions business-as-usual offering (BAU) and more circular offering are respectively used to refer to the original company offering and the offering after the application of the circular measures.

LCC: LCC is the calculation of costs over the whole lifecycle of an object or the part of the lifecycle that a specific actor is responsible for (Sherif \& Kolarik, 1981; Woodward, 1997). This object could be a product, an asset or a product - service system. As a method it precedes the emergence of environmentally oriented lifecycle thinking or sustainability (Hunkeler et al., 2008). It is used for choosing between investment alternatives, optimal budget allocation, calculating trade-offs and identifying uncertainty and risk hot spots (IEC, 2017; Woodward, 1997). Methodological decisions are dependent on the objective (IEC, 2017). Here the term financial LCC (fLCC) is used for the assessment of the economic lifecycle from the viewpoint of one specific actor and covers all internal costs connected to a specific product (Hoogmartens, Van Passel, Van Acker, \& Dubois, 2014). Environmental LCC (eLCC) is the assessment of all costs covered by all actors connected to a specific functional unit and covers internal costs and external costs that are expected to be internalized (Hunkeler et al., 2008). LCC is used to denote both.

CE measures: The CE and the "how to" measures it comprises lack a single universally agreed upon definition. Kirchherr, Reike, and Hekkert (2017) who reviewed all existing definitions, describe the "10R" for product chains developed by Potting, Hekkert, Worrell, and Hanemaaijer (2017), that is, refuse, rethink, reduce, re-use, repair, refurbish, remanufacture, repurpose, recycle and recover, as the most nuanced so it is used in this article. Re-use, repair, refurbish, remanufacture, repurpose are called here "life extension measures" and recycle and recover are called "End-of-life (EOL) measures". The CE or waste hierarchy ranks measures or strategies based on their potential to deliver positive environmental outcomes (European Commission, 2008; Kirchherr et al., 2017). Although only "a rule of thumb", this translates as first avoiding or preventing waste and consumption of materials (reduce), second as extending and intensifying use of products (reuse), third as a next-best option of components (recycling) and finally by recovering energy (recovery) (ibid). These groupings can be further nuanced e.g. reuse is preferable to remanufacture (Potting et al., 2017).

\section{RESEARCH PROCESS}

The guideline for choosing circular measures was developed based on Design Research Methodology (DRM) as presented by Blessing and Chakrabarti (2002). This section starts with a generic description of DRM, followed by a detailed description of its application in this research. Figure 1 depicts the overview of the research process.

\subsection{DESIGN RESEARCH METHODOLOGY}

Design research methodology (DRM) is a methodology for developing guidelines, methods and tools (Blessing \& Chakrabarti, 2010). The first step is to formulate the criterion of success against which the tool will be evaluated after it has been developed. The next stage i.e. Descriptive Study I (DS-I), is to obtain an 
understanding of the phenomenon e.g. current method or process and its influencing factors. To do this literature is used and if not sufficient, then observation of the phenomena is required. In the Prescriptive Study (PS), based on the outcome of the DS-I, a description of the desired situation is generated and then a tool is developed to achieve the desired situation. During the development, the functionality of the tool is tested from the researchers' point of view. In Descriptive Study II (DS-II), the tool is evaluated from a user's point of view and more importantly, it is applied in practice to test it against the success criterion. A specific research project often focuses on one or two stages in the DRM, the scope of this research is shown in Table 1.

\begin{tabular}{|c|c|c|c|}
\hline Criteria formulation & Descriptive Study I & Prescriptive Study & Descriptive Study II \\
\hline Review & Detailed & Detailed & Initial \\
\hline
\end{tabular}

Table 1 Level of detail in research approach

\subsection{CRITERIA FORMULATION}

The overarching goal of this research is to diffuse the implementation of circular measures in established companies. Therefore, the criterion for success is defined as:

The application of the LCC based guideline helps established companies to identify profitable circular measures for their offerings and bring them to the market.

Due to the scope of the research approach, the measurable criterion for this research is defined as:

The participating companies' implementation or intension to implement the circular measures and bring the more circular offerings to the market.

\subsection{DESCRIPTIVE STUdY I (DS-I)}

The purpose of DS-I is to create a better understanding of the phenomena before the tool is developed, namely the process and criteria of selecting circular measures. As advocated in DRM, initially literature was reviewed. Linking profitability to circular measures was identified as a key criterion and subsequently LCC was selected to use in the guideline. Because of a lack of published case studies using LCC to select circular measures as well as detailed descriptions of the process, multiple cases were observed i.e. five products at three companies. Multiple-cases were chosen because they give depth and context for exploration (Given, 2008) and typically provide a stronger base for theory building (Eisenhardt \& Graebner, 2007). More specifically collaboration with the real world is critical to the development and validation of CE tools (Babbitt et al., 2018) and to the sustainability research at large (Sakao \& Brambila-Macias, 2018). The criterion for choosing the companies was that they operated within the linear supply chain for manufactured goods and were interested in improving their offerings in terms of resource efficiency. The importance of the product to the company's portfolio was the main criteria for choosing the products. Case research included observing and participating in the process of choosing circular measures for five products at three companies. The interaction with the case companies cannot be broken down into measurable events as it included meetings, e-mail exchanges, phone calls and commenting on documents. It can be described as participatory but not action oriented (Whyte, 1998). As insights into their process and criteria were obtained, literature was reviewed to gain a theoretical understanding of how LCC could contribute and subsequently LCC results were presented to case companies to gain a practical understanding. This was iterative. The starting point for obtaining literature was the major reviews in "CE" and "LCC" fields and subsequent snowballing. The insights from the cases and the literature jointly produced an understanding of i) circular measure selection and ii) strengths and weakness of LCC in circular decision-making. 


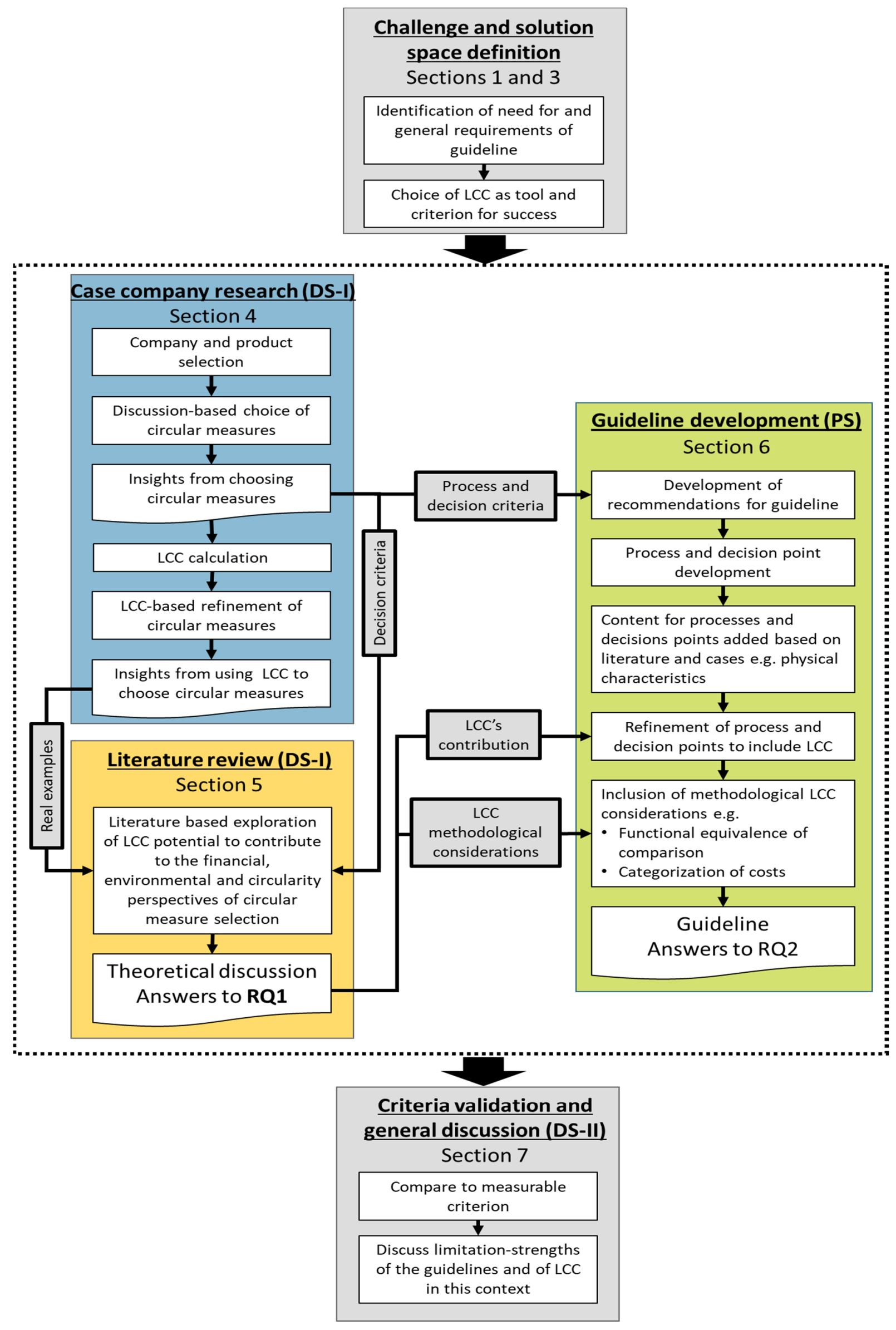

Figure 1 Research process and outcomes 


\subsection{PRESCRIPTIVE STUDY (PS)}

During the PS, the findings of the DS-I, namely the process and decision criteria for selecting circular measures as well as the strengths and weaknesses of using LCC in this process were used to generate a list of recommendations for developing the guideline. The development process was iterative and only the final version is presented.

\subsection{DESCRIPTIVE STUDY II (DS-II)}

Only the initial stage of DS-II was introduced within the scope of the project. The functionality of the tool was tested by retrospectively, applying it to the five offerings to see if its application led to the selection of the same circular measure as those chosen by the case companies during DS-I. Furthermore, the measurable criterion was discussed in a focus group where the authors, the CEO and the environmental/sustainability manager from each company were present.

\section{CASE COMPANY RESEARCH}

This section reports on the case company research and findings. First, the companies, their offerings (BAU) and the circular measures that were selected (more circular offerings) are described. Then the LCC results for the BAU and the more circular offering that were used to inform the selection of the circular measures are presented. Finally, the general insights from observing the companies choose circular measures and use the LCC results are listed.

\subsection{THE COMPANIES AND THEIR OFFERINGS}

Company A is a comprehensive supplier of material and digital visibility solutions e.g., signs, flags, and display walls. Its operations include graphic design, sourcing parts, assembling an order, sale, distribution, installation and storage. Two offerings were assessed: event tents and beach flags sold for single events, e.g., exhibitions. After use, they are discarded but are technically fine (BAU). They have a similar structure, as both consist of a supporting metal frame or fiberglass pole and custom-printed polyester textile. In the circular scenario, the product is refurbished. This is facilitated through rental. After use the products are taken back, the frame or pole is cleaned, stored and eventually refurbished with new textile for another customer. The old textile goes to energy recovery. The frame or pole can be refurbished at least nine times after original use before reaching the end of its technical lifetime and subsequently be recycled.

Company B is a supplier of furniture, e.g., cabinets and recycling stations, for public spaces. Its operations are centred on product design, marketing and administration of the supply chain. Manufacturing, transportation and storage are subcontracted to suppliers and the products are sold via retailers. Two offerings were assessed: recycling bins and lockers that are sold (BAU scenario). The recycling bin is not customized and consists of a steel body and a medium-density fibreboard lid. It is discarded due to technical reasons, most often a damaged lid. In the circular scenario, the bin is repaired. This is facilitated by replacing the lid on demand. The lockers are customized and consist of hardwood case and doors and some steel hinges. They are discarded for aesthetic reasons, e.g., to update the offices' look. In the circular scenario, the lockers are refurbished. This is facilitated by collecting, repainting and redistributing the doors on demand. The doors can be refurbished once and the bin repaired twice before reaching the end of their technical lifetime and going to material or energy recovery.

Company $\mathrm{C}$ offers vacuum waste collection systems for residential areas, business premises and town centres worldwide. This includes inlets, pipes, collection stations, containers, filters, fans, etc. One specific element of the complex system was examined, the inlet where the system user places waste. In contrast to the other cases, Company $\mathrm{C}$ decided on maintenance-repair as the circular measure prior to joining the research because the customized inlets break down due to damage to the door. Therefore, instead of exploring new circular measures, the research focused on examining the effect of redesigning the door for maintenance. 


\subsection{LCC RESULTS}

The LCC results for the BAU and circular offering are depicted in Figure 2. The functional unit for the beach flag and tent was "one item used once", for the lockers and bin was "x storage/waste space used for $y$ years" and for the inlet was "one inlet over y years". LCC methodology details are provided in the supplementary information. The costs have been aggregated into categories to provide an understanding of the changes at various lifecycle stages and circularity as was requested by the companies (Section 4.3). Clarification on the choice of categories is explained with more detail in (Section 5.3). Because cost data are confidential they have been agglomerated, more specifically all costs for each product have been multiplied by a factor. In this way, comparability and transparency are maintained but the actual numbers are masked. The absolute numbers are regarded unnecessary to show the effectiveness of the guideline proposed in this article. The factor for each product is different and was chosen so that the highest cost for that product became 100 . 


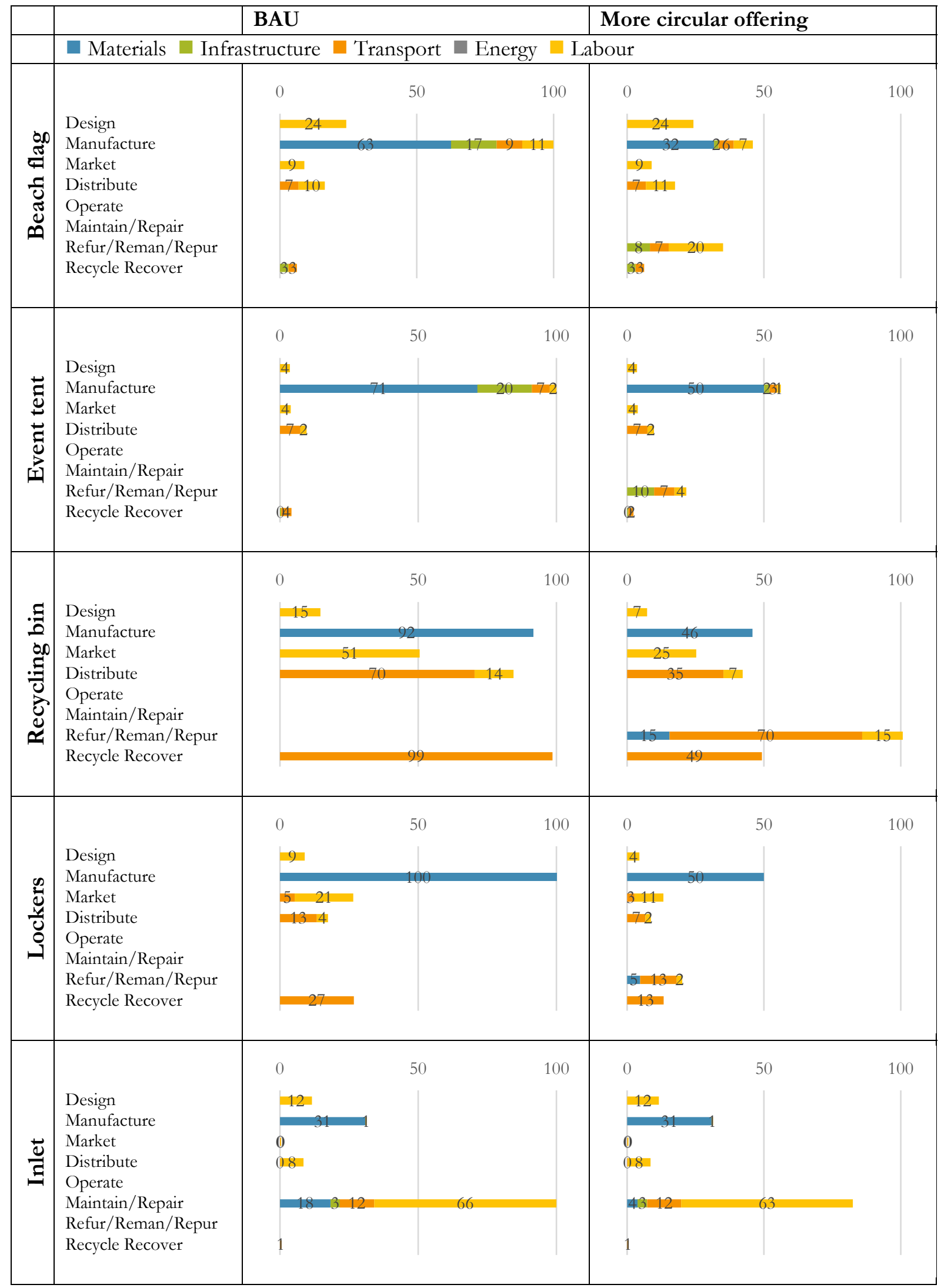

Figure 2 LCC results from BAU and more circular offering at case companies

The numbers have been rounded off to the closest integer 


\subsection{INSIGHTS GAINED FROM CHOOSING CIRCULAR MEASURES AT COMPANIES}

The practitioners' criteria and process when choosing circular measures as well as their experience with using LCC are presented here. Unless specifically stated, these are generally applicable to all the companies involved. The insights are grouped into those related to the general planning and design ( 9 items) and those that are specifically related to LCC (5 items). The former are explained first.

1. Lack of knowledge on circular measures and their hierarchy: The companies did not have comprehensive knowledge on circular measures but saw a high potential of using the hierarchy as a simple guiding principle.

2. Current offerings are the preferred starting pointing: The companies were not interested in brainstorming ideas from a blank slate or exploring options that may involve large investments such as radical innovation or completely changing the business model, they felt that government policies were needed to support such changes. More specifically Company B and A respectively mentioned green public procurement and government funded consultancy. They were more willing to see how changes could be made to their current offerings and to implement pilot projects.

3. Products' technical characteristics determine the potential circular measures: When working with pre-existing products, it immediately became apparent that their technical characteristics and the use case were the first criteria that determined the suitability of circular measures. For example, the event tent is made of customized textile and therefore cannot be reused without modifications.

4. Company profitability is a key criterion: Even if a circular measure were technically possible, the companies would only consider implementing it if it was financially viable and an acceptable solution for the customer.

5. Understand the changes to costs and revenue: Apart from understanding the profitability, the companies needed a more detailed account of how their costs and revenue are affected.

6. Effects on supply chain are a criterion: The effects that implementing a specific circular measure would have on their supply chain members also influenced decision-making.

7. Simple and possible to apply without external help: The companies had limited time and resources to invest. Therefore, they needed guides that they could implement themselves.

8. Understand impacts on circularity: The companies were undertaking these changes driven also by environmental concerns and wished to have a way to measure progress in terms of environmental sustainability.

9. Product design and reduction measures are preceded by the choice of circular measures: The companies thought it was practical to first decide on the main circular measure e.g. "maintenance" and "refurbish" for Companies $\mathrm{C}$ and A respectively and then design the product to fit these measures and explore "reduction" options.

The LCC related insights were gained after introducing LCC to the process and are discussed in more detail in Section 5.

1. LCC of BAU is helpful in choosing the components to be reused.

2. Comparison of LCC is useful to i) assess profitability, ii) identify cost barriers and changes to costs structure and iii) as a basis for deciding pricing strategy.

3. LCC results as visualized in this research and the comparison of material costs can contribute to understanding circularity or resource efficiency.

4. LCC is relatively simple to understand and perform.

5. LCC is a cost calculation and cannot stand alone without more guiding support.

\section{STRENGTHS AND LIMITATIONS OF USING LCC TO SELECT CIRCULAR MEASURES}

The work with the case companies confirmed the position in this research that LCC is both relevant to circular decision-making and implementable. Based on the insights from the companies there are two areas 
that LCC can provide information, the financial perspective, which is imperative and the environmental, and circularity perspective which the companies wish to understand. These are discussed here in further detail and in conjunction with literature to answer R1.

\subsection{LCC AND THE FINANCIAL PERSPECTIVE}

According to Laasch and Conaway (2016) the vast majority of companies engage in responsible business such as $\mathrm{CE}$ with profit as their main motivation. This prioritization was also observed in the case companies. Profit per product/functional unit can be calculated based on both fLCC and eLCC.

If the more circular offering and the BAU are functionally equivalent and the user perceives them to be of equal value, then a user should be willing to pay the same price. In this case, it is enough to compare LCC from the company's perspective between the alternatives. If the alternatives are not functionally equivalent and/or not perceived to be of equal value then a user will not be willing to pay the same price. Revenues will thus change and for profit to be understood they will have to be calculated. Revenues can be included as part of an LCC as long as it is clear how they are being used to avoid double counting and to ensure comparability between the options (Hoogmartens et al., 2014; Hunkeler et al., 2008). Apart from revenues, it can be informative to calculate LCC from the user/customer perspective (Sakao \& Lindahl, 2015). When using fLCC businesses have the advantage of focusing only on the costs they are responsible for, which strengthens simplicity but customer costs are not known and will need to be additionally calculated. On the other hand eLCC although more complex, includes cost information from the whole value chain thereby showing how the application of specific measures can affect other stakeholders (Hunkeler et al., 2008).

For example, for the more circular offering, Company $\mathrm{C}$ changed design of the inlet door so that maintenance required less material input and Company B refurbished the locker doors instead of replacing the whole lockers. The inlet door was considered functionally equivalent and of equal value for the customer and therefore it could be priced at the same level. The lockers were considered functionally equivalent but not of equal value, i.e. customer perceived the new lockers of higher value than the refurbished ones and subsequently the willingness to pay reduced. For the inlet, a comparison of the business' LCC is sufficient to estimate profitability but for the lockers the calculation of revenue and potentially customer costs is necessary. Therefore, to understand profit companies should:

1. compare company fLCC if BAU and circular offering are functionality equivalent and of equal value for the customer; if not then compare company fLCC, revenue and customer fLCC

Research confirms that value can change considerably after the improvement, for both the companies (Matschewsky, Lindahl, \& Sakao, 2018) and the customer (Mont, Plepys, Whalen, \& Nußholz, 2017; Tukker, 2015) and additionally the application of circular measures e.g. repurposing makes defining a product complicated. Therefore, equivalence or lack of it needs to be documented as well as its effects on the decision-making process. LCC is sometimes used to indicate that an alternative is better without considering profitability e.g. Rüdenauer, Gensch, Grießhammer, and Bunke (2005) or the functional equivalence and customer value of the alternatives e.g. Bradley, Jawahir, Badurdeen, and Rouch (2018). They suggest a Total Life Cycle Cost Model (TLCCM), which extends the LCC concept to include multiple lifecycles to be used as the primary engineering-economic model of a CE. They use the product as the unit of analysis without discussing the possibility and consequences that its function and value, either perceived or real may change over time thereby affecting profitability.

A noteworthy limitation of LCC is that most costs are estimates and the value of money changes over time therefore there is inherent uncertainty especially when services are included (Erkoyuncu et al., 2011). Research into minimizing and classifying this uncertainty is ongoing (Kambanou \& Lindahl, 2016).

\subsection{LCC AND THE ENVIRONMENTAL PERSPECTIVE}

Market prices do not reflect environmental and social values and therefore neither fLCC nor eLCC can depict all environmental impacts associated with an offering. LCC only covers environmental and societal 
costs that have been internalized into the economy, and furthermore, these costs have to be assigned to specific actors directly associated with an offering's lifespan (Finnveden \& Moberg, 2005; Gluch \& Baumann, 2004; Hoogmartens et al., 2014; Hunkeler et al., 2008). For example, a hazardous chemical may have a low cost, which is not representative of its critical effect on the environment. Other limitations include, the use of appropriate discount rates, the impact of irreversible decisions and different types of information failures (Gluch \& Baumann, 2004).

LCC could be used in parallel with LCA to understand the trade-offs between environmental impacts and financial implications e.g. (Lindahl et al., 2014; Norris, 2001). LCC and LCA are though not entirely complementary (Hoogmartens et al., 2014) and parallel use of LCA and LCC is still a research topic e.g. (Bierer, Götze, Meynerts, \& Sygulla, 2015; Rüdenauer et al., 2005). LCA is also time consuming and a method which needs expert application (Brick, 2008; D'Incognito et al., 2015), therefore using it comes with a large trade-off in terms of complexity and time, knowledge and resource requirements which makes its implementation difficult. This was confirmed by the case companies, who said that expert support is needed to conduct LCA as well as training to understand the concept. LCA, although beyond the scope of this article, was performed as part of the project to assess the environmental improvements of the circular offerings so this is the basis for the previous statement see Kaddoura, Kambanou, Tillman, and Sakao (2019). To compensate though for the limited environmental perspective, the underlying hierarchy of CE measures which has been created from the perspective of resource efficiency can be used. By using this hierarchy within a guideline, LCC can be a way of checking the financial outcomes from applying CE measures, while the guideline itself leads companies towards choosing those expected to have the best environmental outcomes.

\subsection{LCC AND THE CIRCULARITY PERFORMANCE PERSPECTIVE}

The companies expressed a wish to understand whether the circular measures they selected would contribute to what they vaguely defined as "environmental sustainability". The reason was both motivational as well as for guidance purposes. There is also societal interest in gently pushing companies towards offerings with better environmental outcomes. As discussed in 5.2, LCC is inadequate for assessing environmental impacts e.g. climate change, eutrophication etc. and LCA is not included because of complexity. One of the main aims of CE though is the circularity of resource flows (Blomsma \& Brennan, 2017; Bocken, de Pauw, Bakker, \& van der Grinten, 2016) and LCC can measure these resource flows in terms of costs.

The measurement of circularity is actually an area under development and there is a lack of circularity indicators on the micro-level from the product perspective (Linder, Sarasini, \& van Loon, 2017; Pauliuk, 2018; Saidani et al., 2017). One reason is that currently the definition of CE and circularity at all levels is under construction (Blomsma \& Brennan, 2017; Kirchherr et al., 2017). Based on this ontological confusion, there are different perspectives on what circularity performance is and how it should be measured. Many authors separate circularity from environmental performance. For example, Walker, Coleman, Hodgson, Collins, and Brimacombe (2018) review a number of product level CE indexes concluding that CE indexes should be supported by LCA-based studies and implying that circularity and environmental performance are separate issues. This is similar to Potting et al. (2017) who create separate metrics for circularity and environmental effects of circular strategies. Their circularity metrics measure both materials and energy. Linder et al. (2017), though, argue that a CE index should only measure material circularity and present an aggregate metric based on the economic value of product parts. Pauliuk (2018) presents a dashboard of circularity indexes for companies to choose from depending on the goal, thus emphasizing that a metric is useful in a certain context.

The context in this article is to compare a BAU offering and a more circular offering. Therefore, the measurement only needs to have comparative value and is used for internal decision-making, and not, for example, as a product label or as a generalized expression of its circularity performance. As exemplified above, circularity always includes material considerations and sometimes also energy considerations e.g. (Murray, Skene, \& Haynes, 2017; Potting et al., 2017). Taking the narrower view, circularity is understood in this paper as limiting material flows that are needed to provide a product or functional unit from a lifecycle 
perspective. This understanding of circularity should not be confused with the CE concept which aims at environmental, social, and economic improvements (Kirchherr et al., 2017). Based on this articles' understanding of circularity it is suggested that, "the difference in material costs between the two alternatives" can act as an indicator of circularity performance for alternatives that are functionally equivalent. This feeds off the argumentation by Linder et al. (2017) who propose using "the ratio of recirculated economic value to total product value" as an aggregate circularity metric and suggest using value chain costs to estimate economic value, because costs are one of the best available indicators of material scarcity even though it is limited by market failures. Therefore as guidance companies should aim to achieve and can check performance against the following:

\section{2. material costs in BAU - material costs in circular offering $>0$}

The comparison of material costs indicates the reduction or increase of material needed fulfil the same function in terms of economic value. Therefore it is only applicable when extending LCC to cover the material costs across the whole lifecycle and is associated with a functional unit, otherwise there are risks for burden shifting (Kjaer, Pigosso, McAloone, \& Birkved, 2018). Replacing virgin materials with recycled materials, which is a type of reduction measure, will not be identified by this indicator if the recycled materials are of equal or higher cost. Figure 2 exemplifies visually how the circularity performance based on the above metric improved at the case companies (materials in blue). The case companies experienced this as a useful way of grasping circularity of materials and checking performance even though it was clear to them that it did not depict "environmental sustainability".

To do this the cost elements from LCC needed to be categorized. The categories are case specific but have to include materials. Further suggestions are presented below and were inspired by Hunkeler et al. (2008)'s fourth level of cost categories and Bradley et al. (2018) 's TLCCM model but can be extended e.g. warranties, assurances, settlement cost, control cost. These are:

- Materials e.g., product and auxiliary components and raw materials

- Infrastructure, e.g., machinery, storage or vehicle

- Energy e.g. primary and fuel

- Transport (this is included if it outsourced)

- Labour including administration, maintenance etc

- Environmental costs including legal cost, waste management costs (disposal) and health and safety costs as suggested by Bradley et al. (2018)

If eLCC is used, which includes all costs along the lifecycle then human labour costs can also be an indicator of employment levels. According to some definitions, the allure of CE is that it will increase services and keep employment levels high e.g. International Resource Panel (2017), this though may not coincide with the goals of the business who want to reduce all types of costs. Regardless, by comparing the human labour costs for the BAU and the more circular offering an understanding of the circular measure's effect on employment can be gained. This is one of the strengths of using LCC because labour is included in LCC but not in LCA. The reason is that labour is a high cost driver but not associated with environmental impacts (Hunkeler et al., 2008).

The categorization and visualization of costs not only into types but also into lifecycle stages i.e. cost category level 2 according to (Hunkeler et al., 2008) as depicted in Figure 2 has two other practical uses in circular decision-making. Firstly, it groups together cost elements that should be reduced according to CE principles i.e. materials and energy and those which "should" increase i.e. labour. Based on the premise of exchangeability, meaning cost elements are exchanged to fulfil the same function (Sakao \& Lindahl, 2015) the case companies could understand better and look for opportunities to exchange costs mentioned. Therefore, as guidance companies should aim to:

3. replace material and energy costs in BAU with labour costs in circular offering 
Secondly, it becomes easier to identify cost hotspots or barriers to applying a CE measure. One very specific barrier that companies should try to overcome is high transport costs that can hinder the implementation of environmentally beneficial "life extension measures". The reason is that the environmental impacts from transportation and energy and materials needed to treat a returned product are outweighed by the avoided impacts from less "new product" production. The reason is that a decrease in production has an upstream snowball effect, e.g., reduction of energy and auxiliary materials for production as well as transportation of raw material from extraction through the different manufacturing stages etc. (Baumann \& Tillman, 2004). Therefore, as guidance companies should aim to achieve:

4. avoided costs from production > induced costs from treating returned product

e.g. transport, spare parts and labour

\section{A LCC BASED GUIDELINE FOR SELECTING CIRCULAR MEASURES}

This section presents the guideline and answers RQ2. First the connection between the DS-I and PS is explained and then the guideline in presented. Figure 3 is a process flow chart of the guideline.

\subsection{RECOMMENDATIONS FROM COMPANY INSIGHTS AND LCC DISCUSSION}

The insights obtained from the cases in DS-I as presented in Section 4.3 are connected to specific recommendations for how to develop the guideline. These are presented in Table 2. The discussion of how LCC can provide information on the financial and circularity perspective presented in Section 5 is used for formulating the recommendations. The last column indicates where more detailed information can be found.

\begin{tabular}{|c|c|c|c|}
\hline & Insights & Recommendation & More info \\
\hline \multirow[t]{2}{*}{0} & \multirow[t]{2}{*}{$\begin{array}{l}\text { Goal of the research is resource } \\
\text { efficiency (societal goal) }\end{array}$} & $\begin{array}{l}\text { Guide towards the measures at the top } \\
\text { of the CE hierarchy }\end{array}$ & $\begin{array}{l}\text { Sections } 1 \\
\text { and } 2 \text { and } 5.3\end{array}$ \\
\hline & & $\begin{array}{l}\text { Include the three aims from } 5.3 \text { that } \\
\text { connect LCC cost to the circularity } \\
\text { perspective }\end{array}$ & Section 5.3 \\
\hline 1 & $\begin{array}{l}\text { Lack of knowledge on circular } \\
\text { measures and their hierarchy }\end{array}$ & $\begin{array}{l}\text { Include all circular measures and guide } \\
\text { towards the measures at the top of the } \\
\text { CE hierarchy }\end{array}$ & $\begin{array}{l}\text { Sections } 1 \\
\text { and } 2\end{array}$ \\
\hline 2 & $\begin{array}{l}\text { Current offerings are the preferred } \\
\text { starting point }\end{array}$ & $\begin{array}{l}\text { Not include refuse and rethink } \\
\text { (sharing) in the guideline. }\end{array}$ & Section 7 \\
\hline 3 & $\begin{array}{l}\text { Product's technical characteristics } \\
\text { determine the potential circular } \\
\text { measures }\end{array}$ & $\begin{array}{l}\text { Start from product based criteria to } \\
\text { select relevant measures }\end{array}$ & Section 6.2 \\
\hline 4 & Company profitability is a key criterion & $\begin{array}{l}\text { Use LCC to compare and include of } \\
\text { revenues and customer costs when } \\
\text { necessary }\end{array}$ & $\begin{array}{l}\text { Section1 and } \\
5.1\end{array}$ \\
\hline 5 & $\begin{array}{l}\text { Understand the changes to costs and } \\
\text { revenue }\end{array}$ & Same recommendation as point 4 & Section 5.1 \\
\hline 6 & Effects on supply chain are a criterion & $\begin{array}{l}\text { Consider supply chain in the offering } \\
\text { planning }\end{array}$ & Section 7 \\
\hline 7 & $\begin{array}{l}\text { Simple and possible to apply without } \\
\text { external help }\end{array}$ & Use LCC (and exclude LCA) & $\begin{array}{l}\text { Sections } 5.2 \\
\text { and } 7\end{array}$ \\
\hline 8 & Understand impacts on circularity & $\begin{array}{l}\text { Include the three aims from } 5.3 \text { that } \\
\text { connect LCC cost to the circularity } \\
\text { perspective }\end{array}$ & Section 5.3 \\
\hline
\end{tabular}




\begin{tabular}{|c|l|l|l|}
\hline 9 & $\begin{array}{l}\text { Product design and reduction measures } \\
\text { are preceded by the choice of circular } \\
\text { measure }\end{array}$ & $\begin{array}{l}\text { (Re) design the product, including } \\
\text { choosing reduction measures after } \\
\text { choosing a circular measure }\end{array}$ & Section 6.2 \\
\hline 10 & $\begin{array}{l}\text { LCC of BAU is helpful in choosing the } \\
\text { components to be reused }\end{array}$ & $\begin{array}{l}\text { Calculate LCC of BAU before } \\
\text { formulating circular offering and use } \\
\text { LCC results }\end{array}$ & Section 6.2 \\
\hline 11 & $\begin{array}{l}\text { Comparison of LCC is useful to assess } \\
\text { profitability and identify cost barriers }\end{array}$ & $\begin{array}{l}\text { Confirmation of recommendation for } \\
\text { point 4 }\end{array}$ & $\begin{array}{l}\text { Sections } 1 \\
\text { and 5.1 }\end{array}$ \\
\hline 12 & $\begin{array}{l}\text { Visualization of LCC and comparison } \\
\text { of material costs is useful }\end{array}$ & $\begin{array}{l}\text { Recommend visualization of costs into } \\
\text { categories and confirmation of } \\
\text { recommendation for point } 8\end{array}$ & Section 5.3 \\
\hline 13 & LCC is relatively simple to perform & $\begin{array}{l}\text { Confirmation of recommendation for } \\
\text { point 7 }\end{array}$ & $\begin{array}{l}\text { Sections } 5.2 \\
\text { and 7 }\end{array}$ \\
\hline
\end{tabular}

Table 2 Connection between insights and recommendations for the guideline

\subsection{GUIDELINE}

Based on the recommendations obtained in the previous section, the guideline is formulated as depicted in Figure 3. When there is a change in the information that contributed to the outcome of the guideline, e.g., the reason for EOL changes, then the procedure should be repeated. The repetition can be easily performed if the changes are minor, but may still lead to a different outcome. Below, the guideline is explained step by step. 


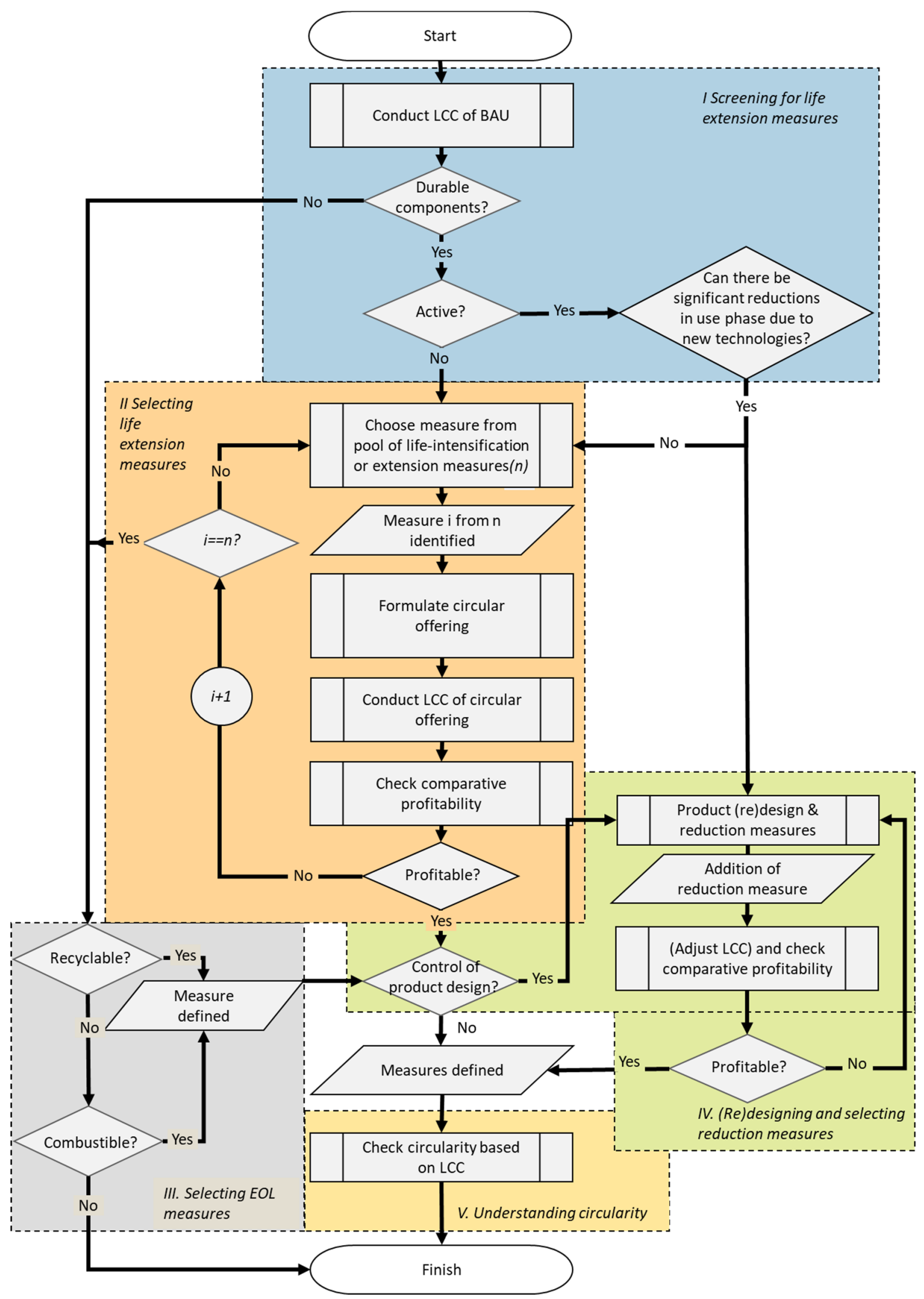

Figure 3 Process flow chart of guideline for selecting circular measures for an offering

$\square_{\text {processes }} \longrightarrow_{\text {decision points }} \square_{\text {start and finish nodes }}$ 


\section{Screening for "life extension measures"}

Not all products are suited to all circular measures therefore the first step is to screen the offering to see if it is suited for "life extension measures".

\section{Process: CONDUCT LCC OF BAU}

LCC for the BAU is performed and the recommendation is to perform eLCC. The results are grouped and visualized according to the cost categories and lifecycle stages described in Section 5.3 and depicted in Figure 2. Because the objective is a comparison, some costs can be left out. For example, fixed costs, which are still incurred even if the production or sales volume falls to zero, can be excluded; e.g. management salaries and payments on loans.

\section{Decision: "Durable components?"}

An offering needs to have at least some durable components to be eligible for "life extension measures" (Willskytt \& Tillman, 2019). If it is non-durable then EOL and reduction measures in Sections III and IV are explored.

\section{Decisions: "Active?" and "Can there be significant reductions in use phase due to new technologies?"}

For active products i.e. that consume energy and materials during the operational phase "life extension measures" might not be suitable when the ongoing technological development can significantly improve the use of energy and consumables (Ardente \& Mathieux, 2014; Cooper \& Gutowski, 2017; Iraldo, Facheris, \& Nucci, 2017). In this case, product (re)design and reduction, as in Section IV, are considered first (Bakker, Wang, Huisman, \& den Hollander, 2014). LCC results can help identify such offerings because the costs for energy and materials during the operation phase are high.

\section{Selecting life extension measures}

In this step, suitable measures from the pool of life extension measures ( $n$ ) are identified.

\section{Process: CHOOSE MEASURE}

The choice is informed by the CE hierarchy and two criteria i.e. customization (yes or no) and the reason for EOL (aesthetic, technical or not needed). The criteria of customization derives from the work at the case companies. The criteria of "reason for EOL" has been well documented in research as crucial to determining strategies to replace EOL (Kobayashi, 2005; Rose, Ishii, \& Stevels, 2002; Umeda et al., 2012) and was corroborated by the case companies. The measure is chosen from decision Table 1 where the first two rows represent the criteria, which have six combinations, e.g., the offering is customized and is discarded for aesthetic reasons and underneath appropriate circular measures are indicated with a check mark. Based on the CE hierarchy, the topmost measure is chosen first as it has the highest potential to increase circularity. This leads to "Outcome: Measure i from n identified"

\begin{tabular}{|c|c|c|c|c|c|c|c|}
\hline \multirow{5}{*}{ Criteria } & Customization & \multicolumn{3}{|c|}{ No } & \multicolumn{3}{c|}{ Yes } \\
\cline { 2 - 8 } & End of life reason & Aesthetic & Technical & $\begin{array}{c}\text { Not } \\
\text { needed }\end{array}$ & Aesthetic & Technical & $\begin{array}{c}\text { Not } \\
\text { needed }\end{array}$ \\
\cline { 2 - 8 } & Reuse & $\checkmark$ & & $\checkmark$ & & & \\
\cline { 2 - 8 } & $\begin{array}{c}\text { Maintenance } \\
\text { Repair }\end{array}$ & & $\checkmark$ & & & $\checkmark$ & \\
\cline { 2 - 8 } & Refurbish & $\checkmark$ & & & $\checkmark$ & & $\checkmark$ \\
\cline { 2 - 8 } & Remanufacture & $\checkmark$ & $\checkmark$ & $\checkmark$ & $\checkmark$ & $\checkmark$ & $\checkmark$ \\
\hline & Repurpose & $\checkmark$ & $\checkmark$ & $\checkmark$ & $\checkmark$ & $\checkmark$ & $\checkmark$ \\
\hline
\end{tabular}

Table 3 Decision table indicating appropriate lifecycle extension measures Tickes indicate that a measure is suitable

\section{Process: Formulate CIRCULAR OFFERING}


Once the measure is preliminarily decided, the offering has to be formulated. That includes for example frequency of maintenance, type of refurbishment, renting or selling and buying back etc. This part is case specific, for example, when defining "refurbishment" for the lockers, the locker doors were chosen because they are the easiest group of components to dismantle, transport and repaint while customers also derive the most aesthetic value from them. Cost can inform this formulation in two ways. Firstly, as presented in Section 5.3, companies should aim to:

\section{replace material and energy costs in BAU with labour costs in circular offering}

Secondly, when choosing components to be kept in the offering or economy e.g. the component to be repurposed, then the opportunities for the component with the highest cost are explored first so that, as presented in Section 5.3:

avoided costs from production > induced costs from treating returned product

e.g. transport, spare parts and labour

\section{Process: CONDUCT LCC OF CIRCULAR OFFERING}

LCC for the circular offering is conducted with the same methodological considerations as the BAU offering.

\section{Process: CHECK COMPARATIVE PROFITABILITY}

The way of assessing profitability based on LCC depends on whether the BAU and more circular alternative are functionally equivalent and of equal value to the customer. As discussed in Section 5.1 the company should:

compare company fLCC if BAU and circular offering are functionality equivalent and of equal value for the customer; if not then compare company fLCC, revenue and customer fLCC

Decision: "Profitable?"

From the previous comparison, the measure is either deemed profitable and therefore appropriate or not. In the latter case, the next best option from Table 2 is chosen; this process is depicted as a loop in Figure 3. If none of the "life extension measures" are appropriate then EOL measures in Section III are considered. If it is profitable then options for product (re)design and reduction in Section IV are considered.

III. Selecting EOL measures

Decisions: "Recyclable?" and "Combustible?"

EOL measures are considered either if an offering is not durable or if none of the "life extension measures" are profitable. Businesses rarely recycle or recover materials themselves, so they can contribute to these measures by designing for them and/or by returning used products to recycle facilities. After one of the measures is chosen i.e. "Outcome: Measure defined", product (re)design and reduction in Section IV is considered.

\section{Product (re)design and selecting reduction measures}

Choices in design of an offering should depend on the lifecycle and business model adopted for the offering to increase the lifecycle performance and maximize the utility of the circular measure, e.g., design for remanufacturing (Alting \& Legarth, 1995; Charter \& Gray, 2008; Umeda et al., 2012). This why the circular measure selection and the formulation of the circular offering precedes the product's design (Sakao \& Shimomura, 2007). The companies also acted according to this principal. The "reduce" measures include reducing energy, materials or auxiliary material use in any of the lifecycle stages or exchanging materials with less impactful ones e.g. recycled materials. Reduction measures are inherently connected to the design stage and are often complementary to or a prerequisite of other circular measures (Bocken et al., 2016). Therefore, the guideline recommends reduction and product (re)design as appropriate actions for all offerings and 
suggests that they are conducted simultaneously. Reductions often sacrifice durability and shift burdens to other lifecycle stages (Kjaer, Pigosso, Niero, Bech, \& McAloone, 2018) therefore businesses should consider the effects of reduction measures on the lifecycle.

Decision: Control of design?

Product (re)design is appropriate if a firm can influence the design stage either by designing themselves or by procuring other components.

\section{Process: PRODUCt (RE)DESIGN \& REDUCTION}

Reduction measures have long been an object of research so there are a number of tools available see for example a review by (Herrmann et al., 2018). Similarly, there are design tools for other circular measures that the company can use and select from e.g. design for remanufacturing (ibid.). Costs here can inform the choices by highlighting cost hot spots e.g. consumables. This process potentially leads to a new design and including reduction measures i.e. "Outcome: $(\mathrm{Re})$ design and addition of reduction measure"

\section{Process: (ADJUST LCC) AND CHECK COMPARATIVE PROFITABILITY}

Cost may change due to (re)design and therefore the LCC of the circular offering is adjusted. This recalculation can also initiate lifecycle thinking and contribute to identifying and understanding burden shifting although it cannot precisely measure or capture environmental impacts (Section 5.2). With this information, designers can revisit their designs and reduction choices. Subsequently, profitability is assessed as described in Section II.

\section{Decision: "Profitable?"}

If the circular offering is not profitable then either the company can repeat (re)design until a profitable solution is found or discard the design changes and/or reduction measures. This leads to "Outcome: Measures defined"

$$
\text { V. Understanding circularity }
$$

\section{Process: CHECK CIRCULARITY BASED ON LCC}

A discussed in 5.3 by comparing the material costs of the BAU and the circular offering the company can obtain an understanding of the circularity performance of the more circular offering compared to BAU. This is only valid if all material costs have been included e.g. spare parts and consumables. If the result is positive then the companies can be more confident that implementation of the circularity measures will contribute to circularity. As discussed in Section 5.3 companies should aim to achieve:

material costs in $B A U$ - material costs in circular offering $>0$

Using material costs as an indicator of a company's performance though is limited to understanding material resource flows connected to the offering in this comparative context and does not depict environmental impacts.

\section{DISCUSSION AND CONCLUSIONS}

\subsection{Discussion}

In this research a guideline to help companies select circular measures for their offerings has been developed. The starting point for developing the guideline was, through research at three case companies, to understand companies' process and decision criteria for selecting circular measures. These are documented as list of insights (Section 4.3) and can be used to learn more about the barriers and drivers for CE on a company level. This is an emerging research field (Kirchherr et al., 2018; Mont et al., 2017) and some of the key 
barriers e.g. lack an understanding of options, hesitant to change, concerned about the financial implications and have limited resources in terms of knowledge and time to invest (Kirchherr et al., 2018; Rizos et al., 2016) were corroborated by the case companies.

The guideline uses LCC to calculate the financial outcomes, which are crucial to companies. By reviewing literature and using LCC at the case companies to inform the choice of circular measures, the strengths, limitations and practical considerations of using LCC are theoretically explored. These are summarized in Table 4 and together with the insights from the companies are used to develop the guideline.

\begin{tabular}{|c|c|c|c|}
\hline & Strengths & Limitations & Considerations \\
\hline Relevance & $\begin{array}{l}\text { - Suited to } \\
\text { product/functional unit } \\
\text { level decision-making } \\
\text { - Familiar monetary } \\
\text { metric } \\
\text { - Broadens decision } \\
\text { makers perspective } \\
\text {-eLCC has a lifecycle } \\
\text { perspective and helps } \\
\text { avoid burden shifting }\end{array}$ & $\begin{array}{l}\text { - Only valid on the micro } \\
\text { level }\end{array}$ & $\begin{array}{l}\text { - fLCC for simplicity or } \\
\text { eLCC for a } \\
\text { comprehensive view of } \\
\text { the lifecycle } \\
\text { - Just an assessment } \\
\text { method so it needs to be } \\
\text { part of a framework or a } \\
\text { guideline }\end{array}$ \\
\hline Implementability & $\begin{array}{l}\text { - Low to medium } \\
\text { complexity } \\
\text { - Limits knowledge and } \\
\text { time input } \\
\text {-Availability of data }\end{array}$ & $\begin{array}{l}\text { - Other stakeholder cost } \\
\text { data hard to obtain } \\
\text { - Need to build cost } \\
\text { models } \\
\text { - Uncertain discount rates }\end{array}$ & $\begin{array}{l}\text { - Discounting rates vs } \\
\text { steady state }\end{array}$ \\
\hline $\begin{array}{l}\text { Financial aspects } \\
\text { \& profitability }\end{array}$ & $\begin{array}{l}\text { - Assessment of } \\
\text { profitability if alternatives } \\
\text { are functionally equivalent } \\
\text { and of equal value } \\
\text { - Focus on costs that can } \\
\text { be influenced (fLCC) }\end{array}$ & $\begin{array}{l}\text { - Uncertainty attached to } \\
\text { calculations }\end{array}$ & $\begin{array}{l}\text { - Revenues and customer } \\
\text { costs may need to be } \\
\text { included if alternatives are } \\
\text { not functionally } \\
\text { equivalent and of equal } \\
\text { value } \\
\text { - Profit maximization vs } \\
\text { profit optimization }\end{array}$ \\
\hline $\begin{array}{l}\text { Environmental } \\
\text { impacts }\end{array}$ & $\begin{array}{l}\text { - Can be used with LCA } \\
\text { and other supplements } \\
\text { e.g. CE hierarchy }\end{array}$ & $\begin{array}{l}\text { - Cannot } \\
\text { comprehensively cover } \\
\text { environmental impacts } \\
\text { due to market and } \\
\text { information failures etc. }\end{array}$ & $\begin{array}{l}\text { - The offering's physical } \\
\text { characteristics e.g. durable } \\
\text { determine the CE } \\
\text { measures that are } \\
\text { applicable }\end{array}$ \\
\hline $\begin{array}{l}\text { Circularity } \\
\text { performance }\end{array}$ & $\begin{array}{l}\text { - Indicator of material } \\
\text { reduction in comparative } \\
\text { context (eLCC) } \\
\text { - Employment indicator } \\
\text { - Includes labour costs } \\
\text { - Identification of cost } \\
\text { barriers to CE measures } \\
\text { e.g. post use transport }\end{array}$ & $\begin{array}{l}\text { - Upstream costs are not } \\
\text { detailed } \\
\text { - Only relevant for } \\
\text { comparison of } \\
\text { alternatives } \\
\text { - fLCC cannot be a } \\
\text { measure of circularity } \\
\text { performance due to } \\
\text { burden shifting }\end{array}$ & $\begin{array}{l}\text { - Categorization required } \\
\text { to promote cost } \\
\text { exchangeability of } \\
\text { materials and energy costs } \\
\text { with labour costs }\end{array}$ \\
\hline
\end{tabular}

Table 4 Strengths, limitations and consideration of using LCC in circular decision-making

DRM (Blessing \& Chakrabarti, 2002) was used to create the guideline. There are currently few guidelines to assist companies with choosing circular measures, therefore efforts that help CE gain momentum are needed (Kirchherr et al., 2018). This is the main contribution to scientific literature. According to DRM, in the DSII step, the guideline should be evaluated against the measurable criterion (see Section 3.2) namely "The participating companies' implementation or intension to implement the circular measures and bring the more circular offerings to the market". This criterion is met because the measures on the inlet and the lockers have been implemented, the measures on the beach flag and event tent are being implemented and only the measure 
on the recycling bin might not be implemented. The reason, as demonstrated in Figure 2, is that the decrease in cost in negligible. To change this situation the company is working with its suppliers to reduce transport costs. This is positive although it is important to remember that change on the micro-level does not automatically mean change on the overall resource flows because of rebound effects (Kjaer, Pigosso, Niero, et al., 2018; Zink \& Geyer, 2017). The DS-II step also includes checking the guidelines' functionality at a wider set of case companies; this is an area for future research. It will be especially important to include active products because one of the limitations of the guideline is that it is developed only based on passive products as cases. Concerning active products there can be environmental benefits of replacing durable products with more energy efficient ones (Ardente \& Mathieux, 2014; Iraldo et al., 2017). Although there is provision for this in the guideline the implications have to be explored in more detail and possibly this guideline can be complemented by, tools targeted at active products with high use costs.

The exclusion LCA from the guideline due to the complexity it adds (Brick, 2008; D'Incognito et al., 2015) comes with the trade-off of accuracy concerning environmental impacts. Finding the right balance so that companies use guidelines but also move toward resource efficient solutions is a constant challenge for academics. It is important to explore the possibilities of using software for automating and reducing complexity (Zhang, Ren, Liu, Sakao, \& Huisingh, 2017). Digital solutions can also support the needed development of guidelines that include both LCA and LCC or similar.

Based on the insights from the companies the guideline starts from pre-existing products, it does not offer the opportunity to the companies to reimagine the future, something which is needed to reap the full benefits of CE (Reike, Vermeulen, \& Witjes, 2018; Tukker, 2004). To this end, other tools need to be developed but equally importantly as mentioned by the companies, policy support is required (Kirchherr et al., 2017; Söderholm \& Tilton, 2012). The companies also mentioned the importance of taking into consideration the effect of a circular measure on other supply chain members. Meeting this requirement is another topic of future research as is exploring how the guideline complements business model development which is crucial issue in CE (Nußholz, 2018).

\subsection{CONCLUSIONS}

Adoption of circular measures by businesses is slow. To stimulate the diffusion of such measures and ultimately support resource efficiency, an LCC based guideline starting from existing offerings and focusing on the financial consequences, which is critical to companies has been developed. The guideline is the main contribution to scientific literature. To develop it, insights on how three collaborating companies selected circular measures and how LCC informed their choice were collected. The documentation of the insights contributes to literature in this field. Based on the insights and LCC literature the strengths and limitations of using LCC were discussed. Accordingly, LCC is found to be relevant and can provide information on financial consequences while also providing some information on resource efficiency/circularity aspects. Key considerations are:

- The companies' LCC can only be used as a measure of profitability if the alternatives are functionally equivalent and of equal value for the customer. Otherwise, revenue and customer costs need to be calculated.

- In this comparative context, "the difference in material cost between the alternatives" can be used to measure circularity performance as long as all materials are included.

- Labour is included in LCC but not in LCA so it can help companies understand and visualize the underlying $\mathrm{CE}$ principle of exchanging material and energy costs with labour costs.

- Companies should aim to decrease production costs and so that they outweigh the induced costs from treating the returned product.

By performing LCC on five offerings before and after the implementation of circular measures, important empirical data is provided. 


\section{SUPPLEMENTARY INFORMATION}

Supplementary information describing the LCC calculation process including objective, equations and cost inventory can be found here: (ink to file in final document)

\section{ACKNOWLEDGEMENT}

This research was supported by the Circularis (Circular Economy through Innovating Design) project (No. 2016-03267), funded by VINNOVA, Sweden's Innovation Agency. We would like to thank the three companies that participated in the research as well as Mohamad Kaddoura, Ryo Fukushima, Ban Ahmad and Aria Soltani for their assistance. We would especially like to express our gratitude to Anne - Marie Tillman for the time she spent and useful inputs to the conceptualization stage. 


\section{REFERENCES}

Allwood, J. M., Ashby, M. F., Gutowski, T. G., \& Worrell, E. (2011). Material efficiency: A white paper. Resources, Conservation and Recycling, 55(3), 362-381. doi:https://doi.org/10.1016/j.resconrec.2010.11.002

Alting, L., \& Legarth, J. B. (1995). Life Cycle Engineering and Design. Annals of CIRP, 44(2), 569-580.

Ardente, F., \& Mathieux, F. (2014). Environmental assessment of the durability of energy-using products: method and application. Journal of Cleaner Production, 74, 62-73. doi:https://doi.org/10.1016/j.jclepro.2014.03.049

Babbitt, C. W., Gaustad, G., Fisher, A., Chen, W.-Q., \& Liu, G. (2018). Closing the loop on circular economy research: From theory to practice and back again. Resources, Conservation and Recycling, 135, 1-2. doi:https://doi.org/10.1016/i.resconrec.2018.04.012

Bakker, C., Wang, F., Huisman, J., \& den Hollander, M. (2014). Products that go round: exploring product life extension through design. Journal of Cleaner Production, 69, 10-16. doi:https://doi.org/10.1016/j.jclepro.2014.01.028

Baumann, H., \& Tillman, A.-M. (2004). The hitchhiker's guide to LCA : an orientation in life cycle assessment methodology and application. Lund: Studentlitteratur.

Bierer, A., Götze, U., Meynerts, L., \& Sygulla, R. (2015). Integrating life cycle costing and life cycle assessment using extended material flow cost accounting. Journal of Cleaner Production, 108, 1289-1301. doi:https://doi.org/10.1016/j.jclepro.2014.08.036

Blessing, L., \& Chakrabarti, A. (2002). DRM - A Design Research Methodology. Paper presented at the Les Sciences de le Conception.

Blessing, L., \& Chakrabarti, A. (2010). DRM, a Design Research Methodology. London: Springer.

Blomsma, F., \& Brennan, G. (2017). The Emergence of Circular Economy: A New Framing Around Prolonging Resource Productivity. Journal of Industrial Ecology, 21(3), 603-614. doi:https://doi.org/10.1111/jiec.12603

Bocken, N. M. P., de Pauw, I., Bakker, C., \& van der Grinten, B. (2016). Product design and business model strategies for a circular economy. Journal of Industrial and Production Engineering, 33(5), 308-320. doi:https://doi.org/10.1080/21681015.2016.1172124

Bradley, R., Jawahir, I. S., Badurdeen, F., \& Rouch, K. (2018). A total life cycle cost model (TLCCM) for the circular economy and its application to post-recovery resource allocation. Resources, Conservation and Recycling, 135, 141-149. doi:https://doi.org/10.1016/j.resconrec.2018.01.017

Brick, K. (2008). Barriers for implementation of the Environmental Load Profile and other LCA-based tools. (2008:16 Licentiate thesis, comprehensive summary), KTH, Stockholm. Retrieved from http://urn.kb.se/resolve?urn=urn:nbn:se:kth:diva-4786 DiVA database.

Charter, M., \& Gray, C. (2008). Remanufacturing and product design. International Journal of Product Development, 6(3/4), 375-392. doi:https://doi.org/10.1504/IJPD.2008.020406

Cooper, D. R., \& Gutowski, T. G. (2017). The Environmental Impacts of Reuse: A Review. Journal of Industrial Ecology, 21(1), 38-56. doi:https://doi.org/10.1111/jiec.12388

D'Incognito, M., Costantino, N., \& Migliaccio, G. C. (2015). Actors and barriers to the adoption of LCC and LCA techniques in the built environment. Built Environment Project and Asset Management, 5(2), 202-216. doi:https://doi.org/10.1108/BEPAM-12-2013-0068

Eisenhardt, K. M., \& Graebner, M. E. (2007). Theory Building from Cases: Opportunities and Challenges. Academy of Management Journal, 50(1), 25-32. doi:https://doi.org/10.5465/amj.2007.24160888

Ellen MacArthur Foundation. (2017). Circular Economy Overview. Retrieved from https://www.ellenmacarthurfoundation.org/circular-economy/overview/concept

Erkoyuncu, J. A., Durugbo, C., Shehab, E., Roy, R., Parker, R., Gath, A., \& Howell, D. (2011). Uncertainty driven service cost estimation for decision support at the bidding stage. International Journal of Production Research, 51(19), 5771-5788. doi:https://doi.org/10.1080/00207543.2013.794318

Directive 2008/98/EC of the European Parliament and of the Council of 19 November 2008 on Waste and Repealing Certain Directives., (2008).

Finnveden, G., \& Moberg, Å. (2005). Environmental systems analysis tools : an overview. Journal of Cleaner Production, 13(12), 1165-1173. doi:https://Ghisellini10.1016/i.jclepro.2004.06.004

Ghisellini, P., Cialani, C., \& Ulgiati, S. (2016). A review on circular economy: the expected transition to a balanced interplay of environmental and economic systems. Journal of Cleaner Production, 114, 11-32. doi:https://doi.org/10.1016/i.jclepro.2015.09.007 
Given, L. M. (2008). The Sage encyclopedia of qualitative research methods: Thousand Oaks : Sage Online, 2008. Gluch, P., \& Baumann, H. (2004). The life cycle costing (LCC) approach: a conceptual discussion of its usefulness for environmental decision-making. Building and Environment, 39(5), 571-580. doi:https://doi.org/10.1016/j.buildenv.2003.10.008

Herrmann, C., Dewulf, W., Hauschild, M., Kaluza, A., Kara, S., \& Skerlos, S. (2018). Life cycle engineering of lightweight structures. CIRP Annals, 67(2), 651-672. doi:https://doi.org/10.1016/j.cirp.2018.05.008

Hoogmartens, R., Van Passel, S., Van Acker, K., \& Dubois, M. (2014). Bridging the gap between LCA, LCC and CBA as sustainability assessment tools. Environmental Impact Assessment Review, 48, 27-33. doi:https://doi.org/10.1016/j.eiar.2014.05.001

Hunkeler, D., Lichtenvort, K., \& Rebitzer, G. (2008). Environmental Life Cycle Costing: Society of Environmental Toxicology and Chemistry (SETAC).

IEC. (2017). Dependability management - Part 3-3: Application guide - Life cycle costing. In (3rd Edition ed.): International Electrotechnical Commission.

International Resource Panel. (2017). Assessing global resource use: A systems approach to resource efficiency and pollution reduction (ISBN: 978-92-807-3677-9). Retrieved from United Nations Environment document repository: http://wedocs.unep.org/bitstream/handle/20.500.11822/22583/Full\%20Report\%20$\% 20$ Assessing\%20Global\%20Resource\%20Use.pdf?sequence=1\&isAllowed =y

Iraldo, F., Facheris, C., \& Nucci, B. (2017). Is product durability better for environment and for economic efficiency? A comparative assessment applying LCA and LCC to two energy-intensive products. Journal of Cleaner Production, 140, 1353-1364. doi:https://doi.org/10.1016/j.jclepro.2016.10.017

Kaddoura, M., Kambanou, M. L., Tillman, A.-M., \& Sakao, T. (2019). Is Prolonging the Lifetime of Passive Durable Products a Low-Hanging Fruit of a Circular Economy? A Multiple Case Study. Sustainability, 11(18), 4819. doi:https://doi.org/10.3390/su11184819

Kambanou, M. L., \& Lindahl, M. (2016). A Literature Review of Life Cycle Costing in the Product-Service System Context. Procedia CIRP, 47, 186-191. doi:https://doi.org/10.1016/j.procir.2016.03.054

Kirchherr, J., Piscicelli, L., Bour, R., Kostense-Smit, E., Muller, J., Huibrechtse-Truijens, A., \& Hekkert, M. (2018). Barriers to the Circular Economy: Evidence From the European Union (EU). Ecological Economics, 150, 264-272. doi:https://doi.org/10.1016/j.ecolecon.2018.04.028

Kirchherr, J., Reike, D., \& Hekkert, M. (2017). Conceptualizing the circular economy: An analysis of 114 definitions. Resources, Conservation and Recycling, 127, 221-232. doi:https://doi.org/10.1016/j.resconrec.2017.09.005

Kjaer, L. L., Pigosso, D. C. A., McAloone, T. C., \& Birkved, M. (2018). Guidelines for evaluating the environmental performance of Product/Service-Systems through life cycle assessment. Journal of Cleaner Production, 190, 666-678. doi:https://doi.org/10.1016/i.jclepro.2018.04.108

Kjaer, L. L., Pigosso, D. C. A., Niero, M., Bech, N. M., \& McAloone, T. C. (2018). Product/Service-Systems for a Circular Economy: The Route to Decoupling Economic Growth from Resource Consumption? Journal of Industrial Ecology, O(0). doi:https://doi.org/10.1111/jiec.12747

Kobayashi, H. (2005). Strategic evolution of eco-products: a product life cycle planning methodology. Research in Engineering Design, 16(1-2), 1-16. doi:https://doi.org/10.1007/s00163-005-0001-3

Laasch, O., \& Conaway, R. (2016). Responsible Business. London: Routledge.

Lieder, M., \& Rashid, A. (2016). Towards circular economy implementation: a comprehensive review in context of manufacturing industry. Journal of Cleaner Production, 115, 36-51. doi:https://doi.org/10.1016/i.jclepro.2015.12.042

Lindahl, M., Sundin, E., \& Sakao, T. (2014). Environmental and economic benefits of Integrated Product Service Offerings quantified with real business cases. Journal of Cleaner Production, 64, 288-296. doi:https://doi.org/10.1016/j.jclepro.2013.07.047

Linder, M., Sarasini, S., \& van Loon, P. (2017). A Metric for Quantifying Product-Level Circularity. Journal of Industrial Ecology, 21(3), 545-558. doi:https://doi.org/10.1111/jiec.12552

Matschewsky, J., Lindahl, M., \& Sakao, T. (2018). Capturing and enhancing provider value in product-service systems throughout the lifecycle: A systematic approach. CIRP Journal of Manufacturing Science and Technology. doi:https://doi.org/10.1016/j.cirpj.2018.08.006

Mont, O., Plepys, A., Whalen, K., \& Nußholz, J. L. (2017). Business model innovation for a circular economy: drivers and barriers for the Swedish industry-the voice of REES companies.

Murray, A., Skene, K., \& Haynes, K. (2017). The Circular Economy: An Interdisciplinary Exploration of the Concept and Application in a Global Context. Journal of Business Ethics, 140(3), 369-380. doi:https://doi.org/10.1007/s10551-015-2693-2 
Norris, G. A. (2001). Integrating life cycle cost analysis and LCA. The International Journal of Life Cycle Assessment, 6(2), 118-120. doi:https://doi.org/10.1007/bf02977849

Nußholz, J. L. K. (2018). A circular business model mapping tool for creating value from prolonged product lifetime and closed material loops. Journal of Cleaner Production, 197, 185-194. doi:https://doi.org/10.1016/j.jclepro.2018.06.112

Pauliuk, S. (2018). Critical appraisal of the circular economy standard BS 8001:2017 and a dashboard of quantitative system indicators for its implementation in organizations. Resources, Conservation and Recycling, 129, 81-92. doi:https://doi.org/10.1016/j.resconrec.2017.10.019

Potting, J., Hekkert, M., Worrell, E., \& Hanemaaijer, A. (2017). Cicular Economy: Measuring innovation in the product chain. Retrieved from https://www.pbl.nl/sites/default/files/cms/publicaties/pbl-2016circular-economy-measuring-innovation-in-product-chains-2544.pdf.

Ranta, V., Aarikka-Stenroos, L., Ritala, P., \& Mäkinen, S. J. (2018). Exploring institutional drivers and barriers of the circular economy: A cross-regional comparison of China, the US, and Europe. Resources, Conservation and Recycling, 135, 70-82. doi:https://doi.org/10.1016/j.resconrec.2017.08.017

Reike, D., Vermeulen, W. J. V., \& Witjes, S. (2018). The circular economy: New or Refurbished as CE 3.0? Exploring Controversies in the Conceptualization of the Circular Economy through a Focus on History and Resource Value Retention Options. Resources, Conservation and Recycling, 135, 246-264. doi:https://doi.org/10.1016/i.resconrec.2017.08.027

Rizos, V., Behrens, A., van der Gaast, W., Hofman, E., loannou, A., Kafyeke, T., .. . Topi, C. (2016). Implementation of Circular Economy Business Models by Small and Medium-Sized Enterprises (SMEs): Barriers and Enablers. Sustainability, 8(11), 1212. doi:https://doi.org/10.3390/su8111212

Rose, C. M., Ishii, K., \& Stevels, A. (2002). Influencing Design to Improve Product End-of-Life Stage. Research in Engineering Design, 13(2), 83-93. doi:https://doi.org/10.1007/s001630100006

Rüdenauer, I., Gensch, C.-O., Grießhammer, R., \& Bunke, D. (2005). Integrated Environmental and Economic Assessment of Products and Processes. Journal of Industrial Ecology, 9(4), 105-116. doi:https://doi.org/10.1162/108819805775248061

Saidani, M., Yannou, B., Leroy, Y., \& Cluzel, F. (2017). How to Assess Product Performance in the Circular Economy? Proposed Requirements for the Design of a Circularity Measurement Framework. Recycling, 2(1), 6. doi:https://doi.org/10.3390/recycling2010006

Sakao, T., \& Brambila-Macias, S. A. (2018). Do we share an understanding of transdisciplinarity in environmental sustainability research? Journal of Cleaner Production, 170, 1399-1403. doi:https://doi.org/10.1016/j.jclepro.2017.09.226

Sakao, T., \& Lindahl, M. (2015). A method to improve integrated product service offerings based on life cycle costing. CIRP Annals - Manufacturing Technology, 64(1), 33-36. doi:http://dx.doi.org/10.1016/i.cirp.2015.04.052

Sakao, T., \& Shimomura, Y. (2007). Service Engineering: a novel engineering discipline for producers to increase value combining service and product. Journal of Cleaner Production, 15(6), 590-604. doi:https://doi.org/10.1016/i.jclepro.2006.05.015

Sherif, Y. S., \& Kolarik, W. J. (1981). Life cycle costing: Concept and practice. Omega, 9(3), 287-296. doi:https://doi.org/10.1016/0305-0483(81)90035-9

Söderholm, P., \& Tilton, J. E. (2012). Material efficiency: An economic perspective. Resources, Conservation and Recycling, 61, 75-82. doi:https://doi.org/10.1016/j.resconrec.2012.01.003

Tomiyama, T., Gu, P., Jin, Y., Lutters, D., Kind, C., \& Kimura, F. (2009). Design methodologies: Industrial and educational applications. Cirp Annals-Manufacturing Technology, 58(2), 543-565. doi:https://doi.org/10.1016/j.cirp.2009.09.003

Tukker, A. (2004). Eight Types of Product-Service System: Eight Ways to Sustainability? Experiences from Suspronet. Business Strategy and the Environment, 13, 246 - 260. doi: https://doi.org/10.1002/bse.414

Tukker, A. (2015). Product services for a resource-efficient and circular economy - a review. Journal of Cleaner Production, 97, 76-91. doi:https://doi.org/10.1016/j.jclepro.2013.11.049

Umeda, Y., Takata, S., Kimura, F., Tomiyama, T., Sutherland, J. W., Kara, S., . . Duflou, J. R. (2012). Toward integrated product and process life cycle planning - An environmental perspective. CIRP Annals Manufacturing Technology, 61(2), 681-702. doi:https://doi.org/10.1016/j.cirp.2012.05.004

Walker, S., Coleman, N., Hodgson, P., Collins, N., \& Brimacombe, L. (2018). Evaluating the Environmental Dimension of Material Efficiency Strategies Relating to the Circular Economy. Sustainability, 10(3), 666. doi:https://doi.org/10.3390/su10030666 
Whyte, W. F. (1998). Rethinking sociology: Applied and basic research. The American Sociologist, 29(1), 16-19. doi:https://doi.org/10.1007/s12108-998-1016-9

Willskytt, S., \& Tillman, A.-M. (2019). Resource efficiency of consumables - Life cycle assessment of incontinence products. Resources, Conservation and Recycling, 144, 13-23. doi:https://doi.org/10.1016/j.resconrec.2018.12.026

Woodward, D. G. (1997). Life cycle costing-Theory, information acquisition and application. International Journal of Project Management, 15(6), 335-344. doi:https://doi.org/10.1016/S0263-7863(96)00089-0

Zhang, Y., Ren, S., Liu, Y., Sakao, T., \& Huisingh, D. (2017). A framework for Big Data driven product lifecycle management. Journal of Cleaner Production, 159, 229-240. doi:https://doi.org/10.1016/j.jclepro.2017.04.172

Zink, T., \& Geyer, R. (2017). Circular Economy Rebound. Journal of Industrial Ecology, 21(3), 593-602. doi:https://doi.org/10.1111/jiec.12545 